\title{
Arsenic hexoxide enhances TNF- $\alpha$-induced anticancer effects by inhibiting NF-кB activity at a safe dose in MCF-7 human breast cancer cells
}

\author{
MIN JEONG KIM ${ }^{1 *}$, JI HYUN JUNG ${ }^{1 *}$, WON SUP LEE ${ }^{1}$, JEONG WON YUN $^{1}$, JING NAN LU ${ }^{1,6}$, SANG MI YI ${ }^{1}$, \\ HYE JUNG KIM ${ }^{2}$, SEONG-HWAN CHANG ${ }^{4}$, GON-SUP KIM ${ }^{5}$, SOON CHAN HONG ${ }^{3}$ and WOO SONG HA ${ }^{3}$ \\ Departments of ${ }^{1}$ Internal Medicine, ${ }^{2}$ Pharmacology and ${ }^{3}$ Surgery, Institute of Health Sciences, Gyeongsang National \\ University School of Medicine, Jinju 660-702; ${ }^{4}$ Department of Surgery, Konkuk University School of Medicine, \\ Seoul 143-701; ${ }^{5}$ School of Veterinary Medicine and Research Institute of Life Science, \\ Gyeongsang National University, Jinju 660-701, Republic of Korea
}

Received January 22, 2014; Accepted February 28, 2014

DOI: 10.3892/or.2014.3085

\begin{abstract}
Arsenic hexoxide $\left(\mathrm{As}_{4} \mathrm{O}_{6}\right)$ has been used in Korean folk remedy for the treatment of cancer since the late 1980s. Evidence suggests that the anticancer effects of $\mathrm{As}_{4} \mathrm{O}_{6}$ are different from those of $\mathrm{As}_{2} \mathrm{O}_{3}$. Tumor necrosis factor- $\alpha$ (TNF- $\alpha$ ) is generally increased in advanced cancer and is closely related to cancer progression, although it has cancer-killing effects. The reason is that TNF- $\alpha$ activates nuclear factor $-\kappa \mathrm{B}(\mathrm{NF}-\kappa \mathrm{B})$ that is involved in cell proliferation, invasion, drug resistance and metastasis. In the present study, we investigated the effects of $\mathrm{As}_{4} \mathrm{O}_{6}$ on NF- $\kappa \mathrm{B}$ activity, NF- $\kappa \mathrm{B}$-mediated cellular responses, and $\mathrm{NF}-\kappa \mathrm{B}-$-regulated gene expressions involved in metastasis at the concentrations of $\mathrm{As}_{4} \mathrm{O}_{6}$ where no cytotoxicity was observed. $\mathrm{As}_{4} \mathrm{O}_{6}$ suppressed $\mathrm{NF}-\kappa \mathrm{B}$ activation in both TNF- $\alpha$-treated and control cells, and also suppressed I $\mathrm{B}$ phosphorylation in a time-dependent manner, suggesting the suppression of $\mathrm{NF}-\kappa \mathrm{B}$ results, in part, from the inhibition of $\mathrm{I} \kappa \mathrm{B}$ degradation. We also confirmed the anti-NF- $\kappa \mathrm{B}$ activity of $\mathrm{As}_{4} \mathrm{O}_{6}$ with synergism with TNF- $\alpha$ by augmenting caspase- 8 activation. $\mathrm{As}_{4} \mathrm{O}_{6}$ also suppressed $\mathrm{NF}-\kappa \mathrm{B}$ activation induced by TNF- $\alpha$, and some of the downstream NF- $\kappa \mathrm{B}$-regulated proteins involved in cancer proliferation, anti-apoptosis and metastasis. In conclusion, the present study demonstrated that $\mathrm{As}_{4} \mathrm{O}_{6}$ has anticancer properties by inhibiting NF- $\kappa \mathrm{B}$ activation and $\mathrm{NF}-\kappa \mathrm{B}$-regulated proteins at least in part through the
\end{abstract}

Correspondence to: Professor Won Sup Lee, Department of Internal Medicine, Institute of Health Sciences and Gyeongnam Regional Cancer Center, Gyeongsang National University School of Medicine, 90 Chilam-dong, Jinju 660-702, Republic of Korea

E-mail: 1wshmo@hanmail.net; lwshmo@gshp.gsnu.ac.kr

Present address: ${ }^{6}$ The Fifth Hospital of Shijiazhuang, Shijiazhuang, Hebei 050021, P.R. China

${ }^{*}$ Contributed equally

Key words: arsenic hexoxide, nuclear factor- $\kappa \mathrm{B}, \mathrm{I} \kappa \mathrm{B}$, cancer inhibition of I $\mathrm{B}$ phosphorylation, especially in the conditions of advanced cancer where TNF- $\alpha$ is highly secreted.

\section{Introduction}

Breast cancer is one of the most common causes of cancerrelated mortality in women, and its incidence is steadily increasing $(1,2)$. It is considered a highly metastatic cancer as a large portion of the patients frequently relapse with systemic dissemination of cancer even after radical extensive surgery (3). In addition, many patients succumb to this disease each year worldwide although many cancer therapeutic methods have been developed for the treatment of breast cancer. Therefore, new treatment strategies are needed for this disease.

Arsenic trioxide $\left(\mathrm{As}_{2} \mathrm{O}_{3}\right)$ was used in Chinese medicine for solid cancer treatment, and is now being used as a standard treatment for refractory acute promyelocytic leukemia (APL) $(4,5)$. Clinical trials with $\mathrm{As}_{2} \mathrm{O}_{3}$ were performed in a certain type of solid cancers $(6,7)$, but failed to prove clinical efficacy due to serious toxicities $(8,9)$. Arsenic hexoxide $\left(\mathrm{As}_{4} \mathrm{O}_{6}\right)$ has been used as a Korean folk remedy for cancer management since the late 1980s. There were scarce toxicities at the doses where $\mathrm{As}_{4} \mathrm{O}_{6}$ was used as a Korean folk remedy for the solid and hematologic malignancies. However, few studies regarding the anticancer effects of $\mathrm{As}_{4} \mathrm{O}_{6}$ have been performed. Only a few reports showed that the anticancer effects of $\mathrm{As}_{4} \mathrm{O}_{6}$ were more potent than those of $\mathrm{As}_{2} \mathrm{O}_{3}$ in human cancer cells in vitro, and that signaling pathways of $\mathrm{As}_{4} \mathrm{O}_{6}$-induced cell death were different from those of $\mathrm{As}_{2} \mathrm{O}_{3}$ (10). We previously demonstrated that $\mathrm{As}_{4} \mathrm{O}_{6}$ induced both caspase-dependent apoptosis and autophagic cell death in human cancer cells (11). In addition, $\mathrm{As}_{4} \mathrm{O}_{6}$ has mostly been used for solid cancers in Korea. The anecdotal cases show some marked responses even in very advanced cancer.

Tumor necrosis factor- $\alpha(\mathrm{TNF}-\alpha)$ is a cytokine involved in systemic inflammation and is produced chiefly by activated macrophages. The primary role of TNF consists in the regulation of immune cells. TNF is able to induce interleukin (IL) production, apoptotic cell death and inflammation to inhibit 
tumorigenesis and viral replication. TNF- $\alpha$ induces cell death through the extrinsic pathway in some cancer cells (12). However, most cancer cells are resistant to TNF- $\alpha$-induced cell death by activation of nuclear factor- $\kappa \mathrm{B}(\mathrm{NF}-\kappa \mathrm{B})$ followed by the enhanced transcription of anti-apoptotic proteins that interfere with cell death signaling (13). High serum level of TNF- $\alpha$ is more frequently observed in patients with advanced and metastatic cancer than in those with early stage cancer (14), and is closely related to cancer progression and patient quality of life $(14,15)$. In addition, NF- $\mathrm{\kappa B}$ is involved in drug resistance as well as metastasis (16). Therefore, NF- $\mathrm{KB}$ is a suitable therapeutic target for cancer treatment. If NF- $\mathrm{KB}$ is suppressed by less toxic drugs, TNF- $\alpha$ induces apoptosis of cancer cells. This will be an alternative approach to treat the patients with metastatic or advanced cancer without showing serious side-effects. We also found the synergism between TNF- $\alpha$ and $\mathrm{As}_{4} \mathrm{O}_{6}$. In the present study, we hypothesized that $\mathrm{As}_{4} \mathrm{O}_{6}$ induced the synergism with TNF- $\alpha$ by the inhibition of NF- $\mathrm{kB}$. Therefore, we explored the anticancer effects of $\mathrm{As}_{4} \mathrm{O}_{6}$ with a particular focus on NF- $\kappa \mathrm{B}$ and NF- $\mathrm{kB}$-regulated gene products involved in cancer metastasis, and on NF- $\mathrm{KB}$ mediated cellular responses in breast cancer cells.

\section{Materials and methods}

Cells and reagents. MCF-7 human breast cancer cells from the American Type Culture Collection (Rockville, MD, USA) were cultured in RPMI-1640 medium (Invitrogen, Carlsbad, CA, USA) supplemented with $10 \%$ (v/v) fetal bovine serum (FBS; Gibco-BRL, Grand Island, NY, USA), $1 \mathrm{mM}$ L-glutamine, $100 \mathrm{U} / \mathrm{ml}$ penicillin, and $100 \mu \mathrm{g} / \mathrm{ml}$ streptomycin at $37^{\circ} \mathrm{C}$ in a humidified atmosphere of $95 \%$ air and $5 \% \mathrm{CO}_{2} . \mathrm{As}_{4} \mathrm{O}_{6}$ was provided by the Chonjisan Institute (Seoul, Korea). Antibodies against procaspase-3, procaspase-8, COX-2, cyclin D1, c-Myc, Bcl-2, Bcl-xL, XIAP, cIAP-1, cIAP-2, MMP-2, MMP-9, VEGF and NF- $\kappa B$ (p65) were purchased from Santa Cruz Biotechnology Inc. (Santa Cruz, CA, USA). Antibodies against

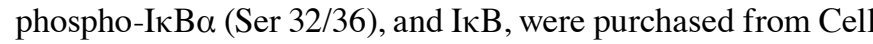
Signaling Technology, Inc. (Beverly, MA, USA). Antibodies against poly(ADP-ribose) polymerase (PARP), LC3 and Beclin-1 were purchased from Pharmingen (San Diego, CA, USA). An antibody against $\beta$-actin was from Sigma (Beverly, MA, USA). Peroxidase-labeled donkey anti-rabbit and sheep anti-mouse immunoglobulins, and an enhanced chemiluminescence (ECL) kit were purchased from Amersham (Arlington Heights, IL, USA). All other chemicals not specifically cited here were purchased from Sigma Chemical Co. (St. Louis, MO, USA). All these solutions were stored at $-20^{\circ} \mathrm{C}$. Stock solutions of DAPI $(100 \mu \mathrm{g} / \mathrm{ml})$ and propidium iodide (PI; $1 \mathrm{mg} / \mathrm{ml})$ were prepared in phosphate-buffered saline (PBS).

Cell viability assays. For the cell viability assay, the cells were seeded onto 24-well plates at a concentration of $5 \times 10^{5}$ cells $/ \mathrm{ml}$, and then treated with the indicated concentration of $\mathrm{As}_{4} \mathrm{O}_{6}$ for 24 or 48 h. 3-(4,5-Dimethylthiazol-2-yl)-2,5diphenyltetrazolium bromide $(0.5 \mathrm{mg} / \mathrm{ml})$ was subsequently added to each well. After $3 \mathrm{~h}$ of additional incubation, $100 \mu \mathrm{l}$ of a solution containing $10 \%$ SDS (pH 4.8) plus $0.01 \mathrm{~N} \mathrm{HCl}$ was added to dissolve the crystals. The absorption values at $570 \mathrm{~nm}$ were determined with an ELISA plate reader.
Nuclear staining. After treatment with the indicated concentration of $\mathrm{As}_{4} \mathrm{O}_{6}$, the cells were harvested, washed with PBS and fixed with $3.7 \%$ paraformaldehyde in PBS for $10 \mathrm{~min}$ at room temperature. Fixed cells were washed with PBS and stained with $2.5 \mu \mathrm{g} / \mathrm{ml}$ 4,6-diamidino-2-phenylindole (DAPI) solution for $10 \mathrm{~min}$ at room temperature. The cells were washed twice with PBS and analyzed under a fluorescent microscope.

Flow cytometry assay. The cells were plated at a concentration of $1 \times 10^{6}$ cells/well in 6-well plates. Reduced (sub-G $\mathrm{G}_{1}$ ) DNA content was measured by PI staining. The DNA content in each cell nucleus was determined with a FACSCalibur flow cytometer (Becton-Dickinson, San Jose, CA, USA). Three independent experiments were performed (17).

Western blot analysis. Total cell lysates were obtained using lysis buffer containing $0.5 \%$ SDS, $1 \% \mathrm{NP}-40,1 \%$ sodium deoxycholate, $150 \mathrm{mM} \mathrm{NaCl}, 50 \mathrm{mM}$ Tris- $\mathrm{Cl}(\mathrm{pH} 7.5)$ and protease inhibitors. The concentrations of cell lysate proteins were determined by Bradford protein assay (Bio-Rad Laboratories, Richmond, CA, USA) using bovine serum albumin as the standard. To determine the protein expression of NF- $\mathrm{KB}$ in the cytoplasm and the nuclei, we prepared separate extracts. The cells were washed with ice-cold PBS (pH 7.4) and lysed in buffer A [10 mM HEPES (pH 7.9), $1.5 \mathrm{mM} \mathrm{MgCl}, 0.5 \mathrm{mM}$ dithiothreitol (DTT), $5 \mu \mathrm{M}$ leupeptin, $2 \mu \mathrm{M}$ pepstatin A, $1 \mu \mathrm{M}$ aprotinin and $20 \mu \mathrm{M}$ phenylmethylsulfonyl fluoride] by repeated freezing and thawing. Nuclear and cytoplasmic fractions were separated by centrifugation at $1,000 \mathrm{x} \mathrm{g}$ for $20 \mathrm{~min}$. The cytoplasmic extract (supernatant) was obtained. The pellets were washed with buffer $\mathrm{A}$, and resuspended in buffer B [10 mM Tris-Cl (pH 7.5), 0.5\% deoxycholate, $1 \%$ NP-40, $5 \mathrm{mM}$ EDTA, $0.5 \mathrm{mM}$ DTT, $5 \mu \mathrm{M}$ leupeptin, $2 \mu \mathrm{M}$ pepstatin $\mathrm{A}, 1 \mu \mathrm{M}$ aprotinin and $20 \mu \mathrm{M}$ phenylmethylsulfonyl fluoride]. The suspension was agitated for $30 \mathrm{~min}$ at $4^{\circ} \mathrm{C}$ and centrifuged at $10,000 \mathrm{x} \mathrm{g}$ for $20 \mathrm{~min}$. The supernatant fraction containing nuclear proteins was collected. Molecular mass markers for proteins were obtained from Pharmacia Biotech (Saclay, France). Thirty micrograms of the lysate proteins were resolved by electrophoresis, electrotransferred to polyvinylidene difluoride membranes (Millipore, Bedford, MA, USA), and then incubated with primary antibodies followed by secondary antibody conjugated to peroxidase. Blots were developed with an ECL detection system.

Transfection. NF- $\kappa \mathrm{B}-$ luciferase constructs (consensus NF- $\mathrm{B}$ binding sequence was cloned into the pGL3 basic luciferase expression vector) were kindly provided by $\mathrm{Dr}$ G. Koretzky (University of Pennsylvania). Transient transfection was performed using Lipofectamine (Gibco-BRL) according to the manufacturer's protocol.

Luciferase assay. After experimental treatments, cells were washed twice with cold PBS, lysed in a passive lysis buffer provided in the dual luciferase kit (Promega, Madison, WI, USA), and assayed for luciferase activity using a TD-20/20 luminometer (Turner Designs, Sunnyvale, CA, USA) according to the manufacturer's protocol. Data were presented as a ratio between Firefly and Renilla luciferase activities. 
A

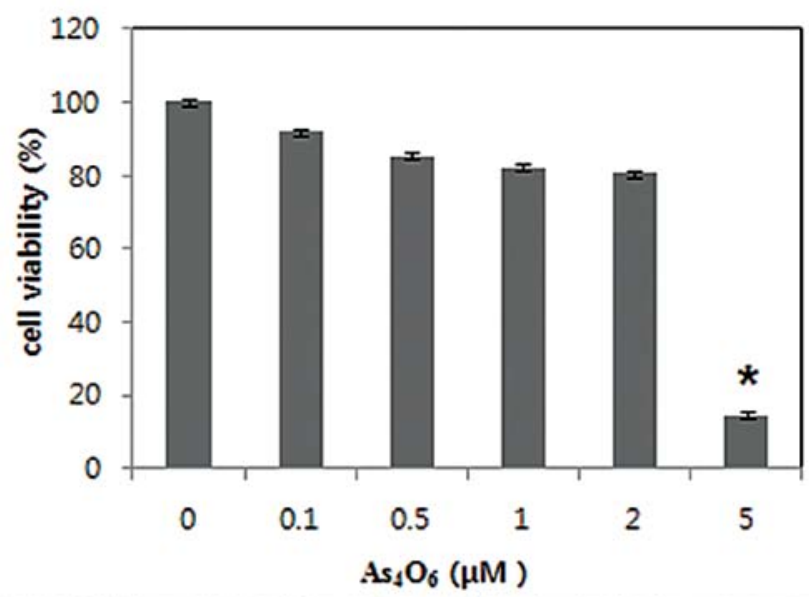

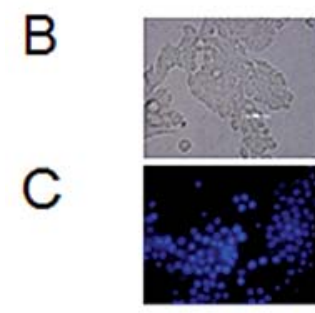

0

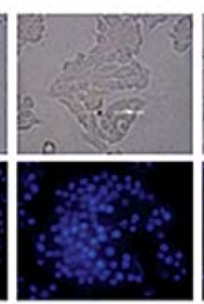

0.1

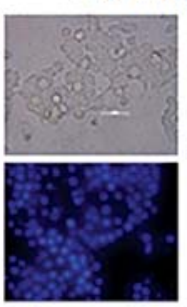

0.5

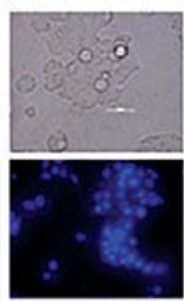

1

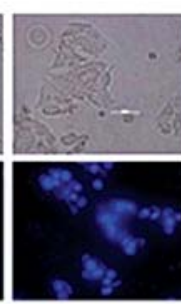

2

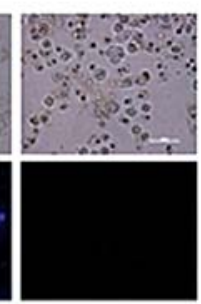

5

Figure 1. Inhibition of cell growth by $\mathrm{As}_{4} \mathrm{O}_{6}$ in MCF-7 human breast cancer cells. The cells were seeded at the density of 5x10 4 cells/ml. The inhibition of cell growth was measured by MTT assay. The cells were treated with the indicated concentrations of $\mathrm{As}_{4} \mathrm{O}_{6}$ for 24 . (A) The growth inhibition and cytotoxicity of $\mathrm{As}_{4} \mathrm{O}_{6}$ are shown at the concentration of $5 \mu \mathrm{M}$, and the $50 \%$ inhibition of cell growth $\left(\mathrm{IC}_{50}\right.$ ) was $>2 \mu \mathrm{M}$. (B) The cells were photographed by an inverted microscope (original magnification, x200). (C) After fixation, the cells were stained with DAPI solution to observe apoptotic body. Stained nuclei were then observed under a fluorescent microscope using a blue filter (original magnification, $\mathrm{x} 400$ ). The data are shown as means \pm SD of three independent experiments. ${ }^{*} \mathrm{P}<0.05$ between the treated and the untreated control group.

Statistical analysis. Each experiment was performed in triplicate. The results are expressed as means \pm SD. Significant differences were determined using the one-way ANOVA with post-test Neuman-Keuls in the cases of at least three treatment groups and Student's t-test for two-group comparison. $\mathrm{P}<0.05$ was considered to indicate a statistically significant difference.

\section{Results}

Effects of $\mathrm{As}_{4} \mathrm{O}_{6}$ on cell growth in MCF-7 human breast cancer cells. To investigate the antitumor activity of $\mathrm{As}_{4} \mathrm{O}_{6}$ in MCF-7 cells, we performed MTT, light microscopic observation, and DAPI staining. Cells were treated for $48 \mathrm{~h}$ with various concentrations of $\mathrm{As}_{4} \mathrm{O}_{6}(0.1-5 \mu \mathrm{M})$. The cell growth was assessed by MTT assay, which revealed that $\mathrm{As}_{4} \mathrm{O}_{6}$ significantly inhibited the growth of MCF-7 cells at the concentration of $5 \mu \mathrm{M}$, and the $50 \%$ inhibition of cell growth $\left(\mathrm{IC}_{50}\right)$ was $>2 \mu \mathrm{M}$ (Fig. 1A). To determine whether the decrease in cell growth of MCF-7 cells was related to induction of cell death and which type of cell death, we assessed the changes in nuclear morphology of $\mathrm{As}_{4} \mathrm{O}_{6}$-treated cells under microscopy with DAPI staining. The DAPI staining revealed that the condensed and fragmented nuclei observed at a concentration of $\geq 2 \mu \mathrm{M}$, and the amount of fragmented nuclei was substantially increased at the concentration of $5 \mu \mathrm{M}$ (Fig. 1B). The present study suggests that $\mathrm{As}_{4} \mathrm{O}_{6}$ induced cell death at the concentrations of $>2 \mu \mathrm{M}$.
Effects of $\mathrm{As}_{4} \mathrm{O}_{6}$ on $\mathrm{NF}-\kappa \mathrm{B}$ and the I $\kappa \mathrm{B} \alpha$ phosphorylation. $\mathrm{NF}-\kappa \mathrm{B}$ comprises a heterotrimer of p50, p65 and I $\mathrm{B} \alpha$ in the cytoplasm; when activated, the heterodimer of p50 and p65 is translocated into the nucleus. Using western blot analysis, we determined whether $\mathrm{As}_{4} \mathrm{O}_{6}$ inhibited $\mathrm{NF}-\kappa \mathrm{B}$ activation at the $1 \mu \mathrm{M}$ where no cytotoxicity was observed. We used TNF- $\alpha$ as an NF- $\kappa \mathrm{B}$ stimulant to clearly demonstrate the effects of $\mathrm{As}_{4} \mathrm{O}_{6}$ on NF- $\kappa \mathrm{B}$. Western blot analysis revealed that treatment with $\mathrm{As}_{4} \mathrm{O}_{6}$ inhibited nuclear $\mathrm{NF}-\kappa \mathrm{B}$ (p65) activity whether TNF- $\alpha$ was co-treated or not. This finding indicated that $\mathrm{As}_{4} \mathrm{O}_{6}$ had clear inhibitory effects on $\mathrm{NF}-\kappa \mathrm{B}$ activation (Fig. 2A). To confirm this finding, we performed the luciferase assay for $\mathrm{NF}-\kappa \mathrm{B}$. As shown in Fig. $2 \mathrm{~B}$, the NF- $\kappa \mathrm{B}$-luciferase activity was augmented by TNF- $\alpha$, which indicated that the $\mathrm{NF}-\kappa \mathrm{B}$ gene was successfully transfected into the cells. The $\mathrm{NF}-\kappa \mathrm{B}-$ luciferase activity induced by $\mathrm{TNF}-\alpha$ was suppressed by $\mathrm{As}_{4} \mathrm{O}_{6}$ (Fig. 2C).

$\mathrm{NF}-\kappa \mathrm{B}$ activation is known to require the degradation of inhibitory $\kappa \mathrm{B} \alpha(\mathrm{I} \kappa \mathrm{B} \alpha)$ through phosphorylation by kinases. Next, we tested whether $\mathrm{As}_{4} \mathrm{O}_{6}$ suppressed TNF- $\alpha$-induced phosphorylation of $\mathrm{I} \kappa \mathrm{B} \alpha$. The degradation of $\mathrm{I} \kappa \mathrm{B} \alpha$ through phosphorylation was observed as early as 5 min after adding TNF- $\alpha$, and 1-h pretreatment with $\mathrm{As}_{4} \mathrm{O}_{6}$ delayed the TNF- $\alpha$ induced phosphorylation of $\mathrm{I} \kappa \mathrm{B} \alpha$ in MCF-7 cells (Fig. 2D). We also observed over $48 \mathrm{~h}$ the effects of $\mathrm{As}_{4} \mathrm{O}_{6}$ on $\mathrm{I} \kappa \mathrm{B} \alpha$ phosphorylation with the TNF- $\alpha$-treated cells. We found that $\mathrm{As}_{4} \mathrm{O}_{6}$ suppressed TNF- $\alpha$-induced phosphorylation of $\mathrm{I} \kappa \mathrm{B} \alpha$ 
A
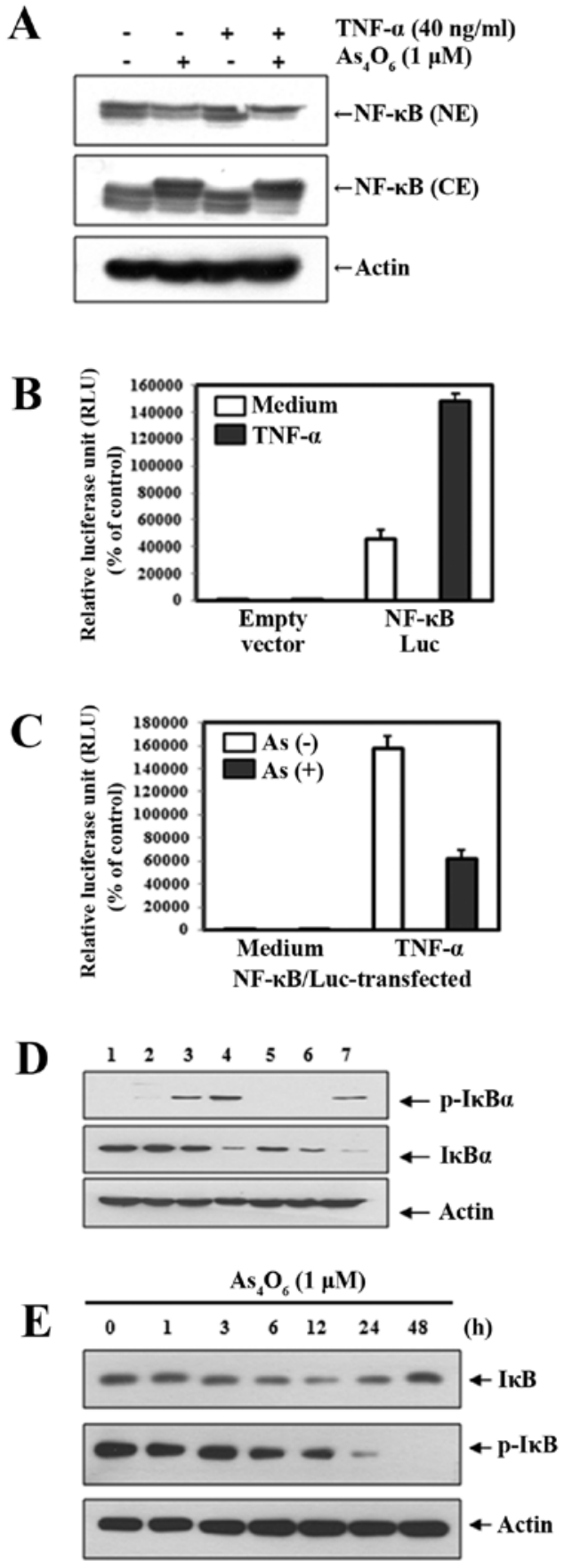

Figure 2. Effects of $\mathrm{As}_{4} \mathrm{O}_{6}$ on NF- $\mathrm{NB}$ and the $\mathrm{I} \kappa \mathrm{B} \alpha$ phosphorylation. (A) Inhibitory effects of $\mathrm{As}_{4} \mathrm{O}_{6}$ on TNF- $\alpha$-induced NF- $\mathrm{kB}$ translocation into the nucleus. Cells were pretreated with $\mathrm{As}_{4} \mathrm{O}_{6}(1 \mu \mathrm{M})$ for $1 \mathrm{~h}$ and then treated with TNF- $\alpha(10 \mathrm{ng} / \mathrm{ml})$ for $30 \mathrm{~min}$. After treatment, nuclear and cytoplasmic fractions were extracted from total cell lysates and protein levels were determined by western blot analysis. (B and C) Cells were transfected with an empty vector or $1 \mu \mathrm{g}$ of NF-kB-luciferase. (B) The cells were allowed to recover for $24 \mathrm{~h}$ and were then treated with $10 \mathrm{ng} / \mathrm{ml}$ of TNF- $\alpha$. (C) The cells were allowed to recover for $24 \mathrm{~h}$ and were then treated with $10 \mathrm{ng} / \mathrm{ml}$ of TNF- $\alpha$ with/without 1-h pretreatment of $\mathrm{As}_{4} \mathrm{O}_{6}(1 \mu \mathrm{M})$. The cells were harvested $1 \mathrm{~h}$ post-treatment with TNF- $\alpha$ and luciferase activities are presented as fold activations relative to those of untreated controls. Each bar graph represents mean $\pm \mathrm{SD}$ of three independent experiments. "P $\mathrm{P} 0.05$ between the treated and the untreated control group. (D and E) Inhibitory effects of $1 \mu \mathrm{M}$ on IkB$\alpha$ phosphorylation. Cells were pretreated with $\mathrm{As}_{4} \mathrm{O}_{6}(1 \mu \mathrm{M})$ for $1 \mathrm{~h}$ and were then treated with TNF- $\alpha(10 \mathrm{ng} / \mathrm{ml})$ for the indicated times. 1 , control; 2-4, TNF- $\alpha$ alone group, 2, 5 and 10 min after TNF- $\alpha$ treatment; 5-7, $\mathrm{As}_{4} \mathrm{O}_{6}+\mathrm{TNF}-\alpha$ group, 2, 5 and 10 min after TNF- $\alpha$ treatment. (E) Cells $\left(5 \times 10^{4}\right.$ cells) were treated with $\mathrm{As}_{4} \mathrm{O}_{6}(1 \mu \mathrm{M})$ for the indicated times in the cells pretreated with TNF- $\alpha(10 \mathrm{ng} / \mathrm{ml})$ and lysed. Data are representative of three independent experiments.

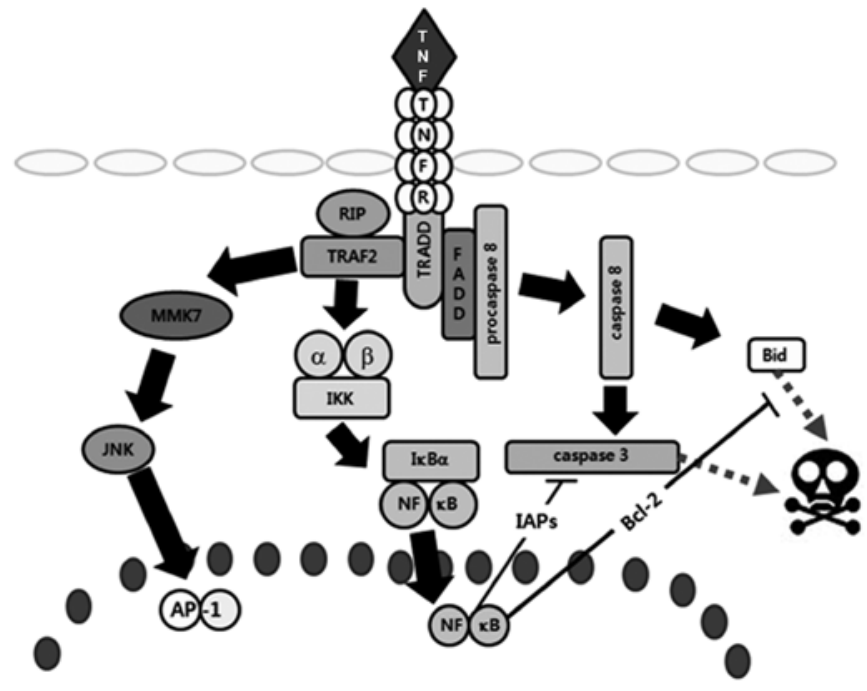

Figure 3. Schematic representation of TNF-R1 signaling pathways and the effects of $\mathrm{As}_{4} \mathrm{O}_{6}$ on MCF-7 human breast cancer cells. When TNF- $\alpha$ binds TNF receptor 1 (TNF-R1), inhibitory protein SODD from the intracellular death domain is dissociated followed by the adaptor protein TRADD binding to the death domain. Subsequently, three pathways can be activated: the MAPK, the NF- $\mathrm{KB}$ and the death signaling pathway. Of the three major MAPK cascades, TNF- $\alpha$ generally induces JNK pathways involved in cell differentiation and proliferation. For activation of NF- $\kappa B$ pathways, TNF- $\alpha$ recruits TRAF2 and RIP through TRADD to activate IKK, then $\operatorname{I\kappa B} \alpha$ is phosphorylated by IKK, and finally activates NF- $\mathrm{KB}$, which induces antiapoptotic proteins (Bcl-2, Bcl-xL, XIAP, cIAP1 and cIAP2) to inhibit the death signaling pathways. For the induction of death signaling, FADD recruits procaspase- 8 by binding to TRADD, and then procaspase- 8 is activated. The activated caspase- 8 leads to apoptosis through activation of caspase- 3 and Bid. Data suggested that $\mathrm{As}_{4} \mathrm{O}_{6}$ may augment TNF- $\alpha$-induced death signaling pathways by suppressing I $\kappa \mathrm{B} \alpha$ phosphorylation.

and the effects became prominent $24 \mathrm{~h}$ after $\mathrm{As}_{4} \mathrm{O}_{6}$ treatment (Fig. 2E). These findings suggest that $\mathrm{As}_{4} \mathrm{O}_{6}$ inhibits NF-kB at least in part through suppression of the IKB $\alpha$ phosphorylation.

$\mathrm{As}_{4} \mathrm{O}_{6}$ suppresses $\mathrm{NF}-\kappa \mathrm{B}$-related cellular responses. We found that $\mathrm{As}_{4} \mathrm{O}_{6}$ clearly inhibited NF- $\mathrm{KB}$ activity in both TNF- $\alpha$-treated cells and control cells. TNF- $\alpha$ is known to be an NF- $\mathrm{kB}$ activator and to bind two receptors, TNF receptor 1 (TNF-R1) and TNF receptor 2 (TNF-R2). Most information of TNF signaling regards TNF-R1 as TNF-R2 is only expressed in immune cells and the mechanism is barely understood. When TNF- $\alpha$ binds to TNF-R1, this binding leads to the adaptor protein TRADD to bind to the death domain. With this binding, three pathways can be initiated: NF- $\mathrm{KB}$, MAPK and death signaling $(18,19)$. The first one is involved in cell survival pathway and the others in pro-apoptotic or death pathway. The former pathway is related to NF- $\mathrm{kB}$ activation. Similar to all death-domain-containing members of the TNF receptor (TNFR) superfamily, TNF-R1 is also involved in death signaling at the same time (20). Therefore, the final results of TNF- $\alpha$ treatment are expressed as the sum of strength regarding TNF-induced cell death and NF- $\kappa B$-related anti-apoptotic effects (Fig. 3). In the present study, we tested the combination effects of TNF- $\alpha$ and $\mathrm{As}_{4} \mathrm{O}_{6}$ to observe whether $\mathrm{As}_{4} \mathrm{O}_{6}$ augments the anticancer effects of TNF- $\alpha$ by suppressing NF- $\mathrm{kB}$ activity. As shown in Fig. $4 \mathrm{~A}, \mathrm{As}_{4} \mathrm{O}_{6}$ potentiated the effects of TNF- $\alpha$ induced cell death. We then 
A

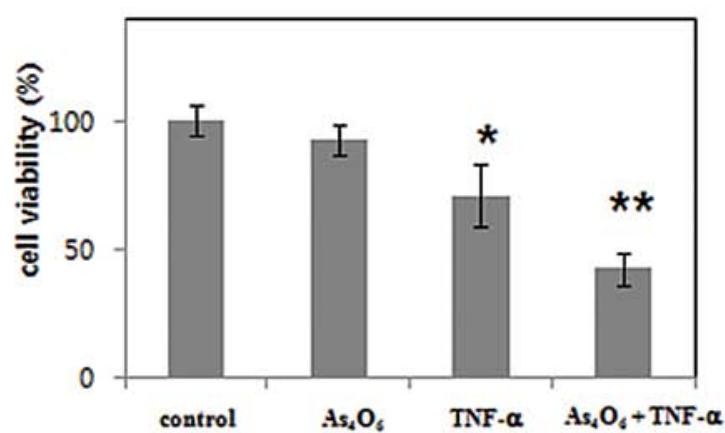

B
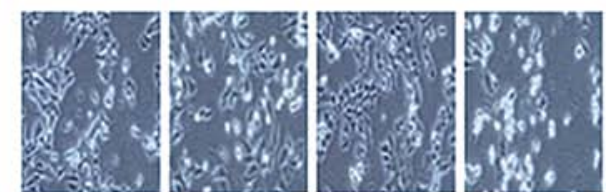

$-$

$+$

C
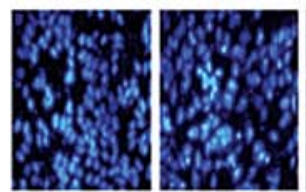

$+$
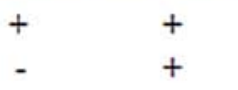

TNF- $\alpha(40 \mathrm{ng} / \mathrm{ml})$ $\mathrm{AS}_{4} \mathrm{O}_{6}(\mathrm{l} \mu \mathrm{M})$
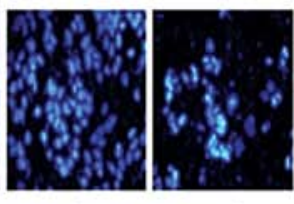

$+$

$+$

$+$

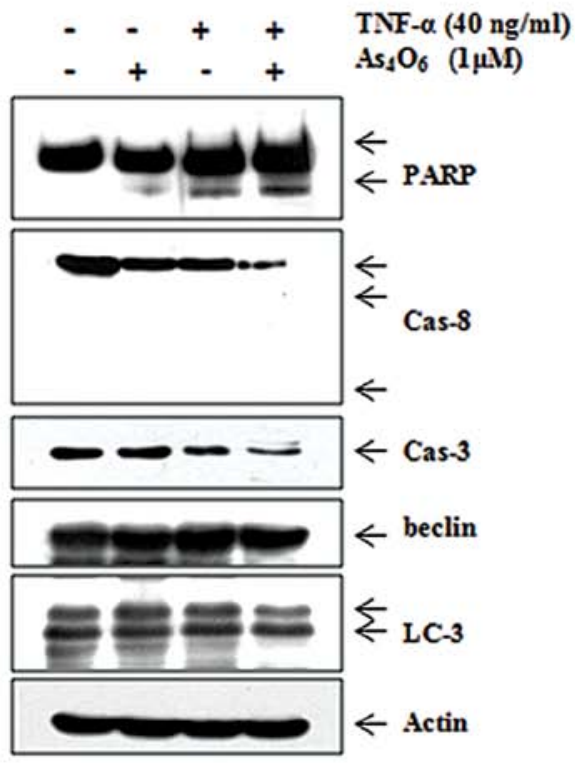

Figure 4. Effects of $\mathrm{As}_{4} \mathrm{O}_{6}$ on NF- $\mathrm{KB}$-related cellular responses. Cells (5x104 cells), either left untreated or pretreated with $\mathrm{As}_{4} \mathrm{O}_{6}$ for $1 \mathrm{~h}$, were exposed to TNF- $\alpha(10 \mathrm{nM})$ for the indicated times. (A) The cells were seeded at the density of $5 \times 10^{4}$ cells $/ \mathrm{ml}$. The inhibition of cell growth was measured by MTT assay. (B) Light microscopic observation. TNF in combination with $\mathrm{As}_{4} \mathrm{O}_{6}$ significantly induced cell death. A large number of floating cells were observed (anoikis). (C) After fixation, the cells were stained with DAPI solution to observe apoptotic body. Stained nuclei were then observed under a fluorescent microscope using a blue filter (original magnification, x200). (D) Cells $\left(5 \times 10^{4}\right.$ cells), either left untreated or pretreated with $\mathrm{As}_{4} \mathrm{O}_{6}$ for $1 \mathrm{~h}$, were exposed to TNF- $\alpha(10 \mathrm{nM})$ for $24 \mathrm{~h}$. Whole-cell extracts were prepared, and $30 \mu \mathrm{g}$ of the whole-cell lysate was analyzed by western blot analysis using the indicated antibodies. The data are shown as means \pm SD of three independent experiments. " $\mathrm{P}<0.05$ between the treated and the untreated control group. ${ }^{* *} \mathrm{P}<0.05$ between the TNF- $\alpha$ and $\mathrm{As}_{4} \mathrm{O}_{6}+\mathrm{TNF}$ group.

assessed the effects of $\mathrm{As}_{4} \mathrm{O}_{6}$ on caspases and their substrates (PARP). TNF- $\alpha$ in combination with $\mathrm{As}_{4} \mathrm{O}_{6}$ significantly decreased the expression levels of procaspase-3, procaspase-8. With the decrease of procaspases, the cleavages of PARP were prominent in the combination treatment group (Fig. 4D). We also assessed the expression of LC-3 (a marker for autophagy) and Beclin-1 to examine whether the augmented cell death by $\mathrm{As}_{4} \mathrm{O}_{6}$ is involved in type II programmed cell death, autophagy. Western blotting revealed that $\mathrm{As}_{4} \mathrm{O}_{6}$ induced LC3 conversion (increase in the ratio of LC3-II/LC3-I), but that the combination with TNF- $\alpha$ did not augment LC3 conversion (Fig. 4D). These findings suggest that $\mathrm{As}_{4} \mathrm{O}_{6}$ augments TNF- $\alpha$-induced apoptosis through extrinsic pathways.

$\mathrm{As}_{4} \mathrm{O}_{6}$ suppresses $\mathrm{NF}-\kappa \mathrm{B}$-regulated proteins involved in anti-apoptosis, proliferation, invasion and angiogenesis. We also observed that $\mathrm{As}_{4} \mathrm{O}_{6}$ inhibited NF- $\mathrm{BB}$-related cellular response. $\mathrm{NF}-\kappa \mathrm{B}$ also regulates several genes involved in cancer metastasis. We investigated the effects of $\mathrm{As}_{4} \mathrm{O}_{6}$ on the $\mathrm{NF}-\kappa \mathrm{B}-$-regulated proteins involved in anti-apoptosis, proliferation, invasion and angiogenesis. We found that TNF- $\alpha$ stimulated the $\mathrm{NF}-\kappa \mathrm{B}$-regulated proteins involved in anti- apoptosis (c-IAP1, c-IAP2, XIAP, Bcl-2 and Bcl-xL) (Fig. 5A), cancer cell proliferation (COX-2, c-Myc and cyclin D1) (Fig. 5B), and invasion and angiogenesis (MMP-2, MMP-9 and VEGF) (Fig. 5C). $\mathrm{As}_{4} \mathrm{O}_{6}$ suppressed the TNF- $\alpha$-induced $\mathrm{NF}-\kappa \mathrm{B}-$ regulated proteins involved in anti-apoptosis, proliferation, invasion and angiogenesis in MCF-7 cells (Fig. 5). These findings also support that $\mathrm{As}_{4} \mathrm{O}_{6}$ suppresses $\mathrm{NF}-\kappa \mathrm{B}$ activity, and that it has anticancer properties especially in conditions of advanced or metastatic cancer where TNF- $\alpha$ is highly secreted from activated macrophages or cancer cells themselves.

\section{Discussion}

With the assumption that $\mathrm{As}_{4} \mathrm{O}_{6}$ inhibits $\mathrm{NF}-\kappa \mathrm{B}$ at a safe concentration, showing anticancer effects without serious side-effects in advanced cancer where TNF- $\alpha$ is highly secreted, we investigated the anticancer effects of $\mathrm{As}_{4} \mathrm{O}_{6}$ with a particular focus on NF- $\kappa$ B pathway, NF- $\kappa$ B-regulated gene products, and NF- $\kappa \mathrm{B}$-mediated cellular responses in human breast cancer cells. In the present study, $\mathrm{As}_{4} \mathrm{O}_{6}$ inhibited $\mathrm{NF}-\kappa \mathrm{B}$ activity and $\mathrm{NF}-\kappa \mathrm{B}-$ regulated proteins at the concentrations where no cytotoxicity was observed, indicating that it 


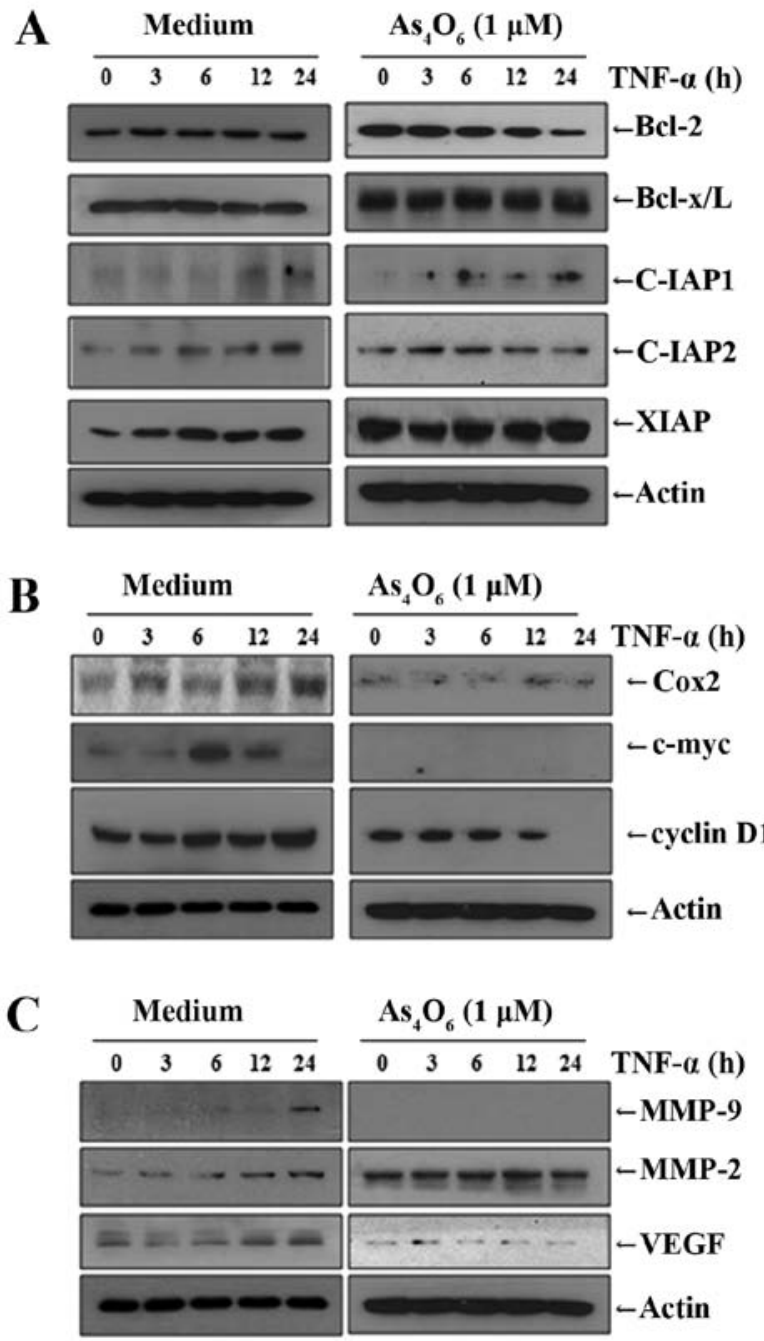

Figure 5. Effects of $\mathrm{As}_{4} \mathrm{O}_{6}$ on NF- $\mathrm{NB}$-regulated proteins involved in antiapoptosis, proliferation, invasion and angiogenesis. Cells $\left(5 \times 10^{4}\right.$ cells $)$, either left untreated or pretreated with $\mathrm{As}_{4} \mathrm{O}_{6}$ for $1 \mathrm{~h}$, were exposed to TNF- $\alpha$ $(10 \mathrm{nM})$ for the indicated times. Whole-cell extracts were prepared, and $30 \mu \mathrm{g}$ of the whole-cell lysate was analyzed by western blot analysis using antibodies against various $\mathrm{NF}-\kappa \mathrm{B}$-regulated proteins involved in (A) the anti-apoptosis, (B) cancer cell proliferation, and (C) invasion (MMP-2 and MMP-9), and angiogenesis (VEGF). Data are representative of two independent experiments.

can induce anticancer effects without definite side-effects and may be used for maintenance therapy. In addition, $\mathrm{As}_{4} \mathrm{O}_{6}$ can be used in combination with conventional chemotherapeutics without increasing toxicity since the activation of $N F-\kappa B$ is one of the drug resistance mechanisms. Bortezomib is a good example; it is a proteasome inhibitor that has inhibitory effects on $\mathrm{NF}-\kappa \mathrm{B}$ by suppressing I $\kappa \mathrm{B} \alpha$ degradation (21); it can be used in combination with conventional agents and for maintenance therapy.

$\mathrm{As}_{4} \mathrm{O}_{6}$ also augmented the TNF- $\alpha$-induced cell death in MCF-7 cells. The evidence supports that arsenic compounds could suppress NF- $\kappa$ B activation $(22,23)$. However, $\mathrm{As}_{4} \mathrm{O}_{6}$ showed the inhibitory effect on $\mathrm{NF}-\kappa \mathrm{B}$ at a concentration showing no cytotoxicity. This is the first report regarding anti$\mathrm{NF}-\kappa \mathrm{B}$ effects of $\mathrm{As}_{4} \mathrm{O}_{6}$.

TNF- $\alpha$ induces cell death through the extrinsic pathway in some cells, such as MCF-7 cells (12), but most cancer cell lines are resistant to TNF- $\alpha$-induced cell death as its death-inducing ability is weak and often masked by $\mathrm{NF}-\kappa \mathrm{B}$ activation followed by the enhanced transcription of anti-apoptotic proteins (13). In the present study, we demonstrated that $\mathrm{As}_{4} \mathrm{O}_{6}$ enhanced the anticancer effects of TNF- $\alpha$ by inhibiting NF- $\kappa$ B. In TNF- $\alpha-$ resistant cells, $\mathrm{As}_{4} \mathrm{O}_{6}$ in combination with $\mathrm{TNF}-\alpha$ showed synergism (data not shown). TNF- $\alpha$ is generally increased in patients with advanced and metastatic cancer and is associated with cancer progression and patient quality of life $(14,15)$. Furthermore, TNF- $\alpha$ is abundantly released in chronic inflammatory disorders including rheumatoid arthritis as well, and a TNF- $\alpha$ inhibitor is used to control the chronic inflammatory disorders (24). However, the direct inhibition of TNF- $\alpha$ raises some suspicion that it may cause cancer development in chronic inflammatory disorders (24). The present study suggests that TNF- $\alpha$ can be used as a therapeutic tool by inhibiting NF- $\kappa \mathrm{B}$ activation in advanced and metastatic cancers.

In the present study, we also investigated the inhibitory effects of $\mathrm{As}_{4} \mathrm{O}_{6}$ on MMP-2 and MMP-9 expression in TNF- $\alpha$ treated cells. MMP-2 and MMP-9 are key molecules in cancer cell invasion $(25,26)$ which have been targets for drug development against cancer invasion (27). We also found that $\mathrm{As}_{4} \mathrm{O}_{6}$ suppressed COX-2, cyclin D1 and c-Myc involved in cell proliferation. COX-2 is overexpressed in a variety of cancers and mediates cancer cell proliferation $(13,28,29)$ and c-Myc is also involved in cancer cell proliferation (30). In addition, VEGF is an angiogenic factor (13). Both are important in metastasis and are regulated by $\mathrm{NF}-\kappa \mathrm{B}(13,28)$. The I $\mathrm{B}$ family consists of $\mathrm{I} \kappa \mathrm{B} \alpha, \mathrm{I} \kappa \mathrm{B} \beta, \mathrm{I} \kappa \mathrm{B} \varepsilon$ and $\mathrm{Bcl}-3$. Among them, $\mathrm{I} \kappa \mathrm{B} \alpha$ is the most extensively studied and major $\mathrm{I} \kappa \mathrm{B}$ protein. $\mathrm{NF}-\kappa \mathrm{B}$ activation is initiated by the degradation of $\mathrm{I} \kappa \mathrm{B} \alpha$ protein which is an inhibitor of NF- $\kappa \mathrm{B}$. The degradation of I $\kappa \mathrm{B} \alpha$ occurs through the activation of $\mathrm{I}_{\kappa} \mathrm{B}$ kinase (IKK). When activated by signals, the I $\mathrm{B}$ kinase phosphorylates two serine residues located in an $\mathrm{I} \kappa \mathrm{B} \alpha$ regulatory domain. When phosphorylated $\mathrm{I} \kappa \mathrm{B} \alpha$ at serines 32 and 36 , the $\mathrm{I} \kappa \mathrm{B} \alpha$ is degraded by ubiquitination (31). Here, we found that $\mathrm{As}_{4} \mathrm{O}_{6}$ suppressed phosphorylation of $\mathrm{I} \kappa \mathrm{B} \alpha$. This finding suggests that the anti-NF- $\mathrm{B}$ activities of $\mathrm{As}_{4} \mathrm{O}_{6}$ are contributed by suppression of $\mathrm{I} \kappa \mathrm{B} \alpha$ phosphorylation.

In conclusion, the present study demonstrated that $\mathrm{As}_{4} \mathrm{O}_{6}$ has anticancer properties by inhibiting $\mathrm{NF}-\kappa \mathrm{B}$ activation and $\mathrm{NF}-\kappa \mathrm{B}$-regulated proteins at least in part through the inhibition of I $\mathrm{B}$ phosphorylation, especially in conditions of advanced or metastatic cancer where TNF- $\alpha$ is highly secreted (Fig. 3). The present study provides evidence that $\mathrm{As}_{4} \mathrm{O}_{6}$ may have anticancer effects through inhibiting NF- $\kappa \mathrm{B}$ activity in human breast cancer.

\section{Acknowledgements}

The present study was supported by a grant from the National Research Foundation of Korea (NRF) funded by the Korea government (MEST) (no. 20120002631).

\section{References}

1. Kamangar F, Dores GM and Anderson WF: Patterns of cancer incidence, mortality, and prevalence across five continents: defining priorities to reduce cancer disparities in different geographic regions of the world. J Clin Oncol 24: 2137-2150, 2006 . 
2. Jung KW, Park S, Kong HJ, Won YJ, Lee JY, Seo HG, et al: Cancer statistics in Korea: incidence, mortality, survival, and prevalence in 2009. Cancer Res Treat 44: 11-24, 2012.

3. Nguyen DX and Massague J: Genetic determinants of cancer metastasis. Nat Rev Genet 8: 341-352, 2007.

4. Shen ZX, Chen GQ, Ni JH, Li XS, Xiong SM, Qiu QY, et al: Use of arsenic trioxide $\left(\mathrm{As}_{2} \mathrm{O}_{3}\right)$ in the treatment of acute promyelocytic leukemia (APL): II. Clinical efficacy and pharmacokinetics in relapsed patients. Blood 89: 3354-3360, 1997.

5. Niu C, Yan H, Yu T, Sun HP, Liu JX, Li XS, et al: Studies on treatment of acute promyelocytic leukemia with arsenic trioxide: remission induction, follow-up, and molecular monitoring in 11 newly diagnosed and 47 relapsed acute promyelocytic leukemia patients. Blood 94: 3315-3324, 1999.

6. Munshi NC, Tricot G, Desikan R, Badros A, Zangari M, Toor A et al: Clinical activity of arsenic trioxide for the treatment of multiple myeloma. Leukemia 16: 1835-1837, 2002.

7. Lin YC, Li DR and Lin W: Relationship between radiotherapy enhancing effect of arsenic trioxide and the proliferation and apoptosis of related protein in nasopharyngeal carcinoma patients. Zhongguo Zhong Xi Yi Jie He Za Zhi 27: 704-707, 2007 (In Chinese)

8. Welch JS, Klco JM, Gao F, Procknow E, Uy GL, StockerlGoldstein KE, et al: Combination decitabine, arsenic trioxide, and ascorbic acid for the treatment of myelodysplastic syndrome and acute myeloid leukemia: a phase I study. Am J Hematol 86: 796-800, 2011.

9. Beer TM, Tangen CM, Nichols CR, Margolin KA, Dreicer R, Stephenson WT, et al: Southwest Oncology Group phase II study of arsenic trioxide in patients with refractory germ cell malignancies. Cancer 106: 2624-2629, 2006.

10. Chang HS, Bae SM, Kim YW, Kwak SY, Min HJ, Bae IJ, et al: Comparison of diarsenic oxide and tetraarsenic oxide on anticancer effects: Relation to the apoptosis molecular pathway. Int J Oncol 30: 1129-1135, 2007.

11. Han MH, Lee WS, Lu JN, Yun JW, Kim G, Jung JM, et al: Tetraarsenic hexoxide induces Beclin-1-induced autophagic cell death as well as caspase-dependent apoptosis in U937 human leukemic cells. Evid Based Complement Alternat Med 2012: 201414, 2012

12. Messmer UK, Pereda-Fernandez C, Manderscheid M and Pfeilschifter J: Dexamethasone inhibits TNF- $\alpha$-induced apoptosis and IAP protein downregulation in MCF-7 cells. Br J Pharmacol 133: 467-476, 2001.

13. Aggarwal BB: Nuclear factor- $\mathrm{kB}$ : the enemy within. Cancer Cell 6: 203-208, 2004.

14. Correia M, Cravo M, Marques-Vidal P, Grimble R, DiasPereira A, Faias S, et al: Serum concentrations of TNF-alpha as a surrogate marker for malnutrition and worse quality of life in patients with gastric cancer. Clin Nutr 26: 728-735, 2007.
15. Tas F, Duranyildiz D, Argon A, Oguz H, Camlica H, Yasasever V, et al: Serum levels of leptin and proinflammatory cytokines in advanced-stage non-small cell lung cancer. Med Oncol 22: 353-358, 2005

16. Guttridge DC, Albanese C, Reuther JY, Pestell RG and Baldwin AS Jr: NF- $\kappa \mathrm{B}$ controls cell growth and differentiation through transcriptional regulation of cyclin D1. Mol Cell Biol 19: 5785-5799, 1999.

17. Cui ZG, Hong NY, Guan J, Kang HK, Lee DH, Lee YK, et al: cAMP antagonizes ERK-dependent antiapoptotic action of insulin. BMB Rep 44: 205-210, 2011.

18. Wajant H,Pfizenmaier K and Scheurich P: Tumor necrosis factor signaling. Cell Death Differ 10: 45-65, 2003.

19. Chen G and Goeddel DV: TNF-R1 signaling: a beautiful pathway. Science 296: 1634-1635, 2002.

20. Gaur U and Aggarwal BB: Regulation of proliferation, survival and apoptosis by members of the TNF superfamily. Biochem Pharmacol 66: 1403-1408, 2003.

21. Demchenko YN and Kuehl WM: A critical role for the NFкB pathway in multiple myeloma. Oncotarget 1: 59-68, 2010.

22. Kerbauy DM, Lesnikov V, Abbasi N, Seal S, Scott B and Deeg HJ: NF- $\kappa \mathrm{B}$ and FLIP in arsenic trioxide (ATO)-induced apoptosis in myelodysplastic syndromes (MDSs). Blood 106: 3917-3925, 2005.

23. Han SS, Kim K, Hahm ER, Park CH, Kimler BF, Lee SJ, et al: Arsenic trioxide represses constitutive activation of $\mathrm{NF}-\mathrm{\kappa B}$ and COX-2 expression in human acute myeloid leukemia, HL-60. J Cell Biochem 94: 695-707, 2005.

24. Jamnitski A, Levels JH, Oever IA and Nurmohamed MT: Highdensity lipoprotein profiling changes in patients with rheumatoid arthritis treated with tumor necrosis factor inhibitors: a cohort study. J Rheumatol 40: 825-830, 2013.

25. Davies B, Waxman J, Wasan H, Abel P, Williams G, Krausz T, et al: Levels of matrix metalloproteases in bladder cancer correlate with tumor grade and invasion. Cancer Res 53: 5365-5369, 1993

26. Bogenrieder T and Herlyn M: Axis of evil: molecular mechanisms of cancer metastasis. Oncogene 22: 6524-6536, 2003.

27. Vihinen P and Kahari VM: Matrix metalloproteinases in cancer: prognostic markers and therapeutic targets. Int J Cancer 99: $157-166,2002$.

28. Gilmore TD: Introduction to NF- $\kappa \mathrm{B}$ : players, pathways, perspectives. Oncogene 25: 6680-6684, 2006.

29. Chun KS and Surh YJ: Signal transduction pathways regulating cyclooxygenase-2 expression: potential molecular targets for chemoprevention. Biochem Pharmacol 68: 1089-1100, 2004.

30. Schmidt EV: The role of c-myc in regulation of translation initiation. Oncogene 23: 3217-3221, 2004.

31. Chen ZJ, Parent L and Maniatis T: Site-specific phosphorylation of I $\mathrm{B} \alpha$ by a novel ubiquitination-dependent protein kinase activity. Cell 84: 853-862, 1996. 